\title{
Immunoglobulin gene translocations in chronic lymphocytic leukemia: A report of 35 patients and review of the literature
}

\author{
MARC DE BRAEKELEER ${ }^{1-3}$, CORINE TOUS $^{3}$, NADIA GUÉGANIC ${ }^{1,2}$, MARIE-JOSÉE LE BRIS $^{3}$, \\ AUDREY BASINKO ${ }^{2,3}$, FRÉDÉRIC MOREL ${ }^{1-3}$ and NATHALIE DOUET-GUILBERT ${ }^{1-3}$ \\ ${ }^{1}$ Faculty of Medicine and Health Sciences, University of Brest; ${ }^{2}$ National Institute of Health and Medical Research \\ (INSERM U1078); ${ }^{3}$ Department of Cytogenetics and Reproductive Biology, Morvan Hospital, \\ Regional University Hospital Center of Brest (CHRU), Brest, France
}

Received December 30, 2015; Accepted February 9, 2016

DOI: $10.3892 / \mathrm{mco} .2016 .793$

\begin{abstract}
Chronic lymphocytic leukemia (CLL) represents the most common hematological malignancy in Western countries, with a highly heterogeneous clinical course and prognosis. Translocations involving the immunoglobulin (IG) genes are regularly identified. From 2000 to 2014, we identified an IG gene translocation in 18 of the 396 patients investigated at diagnosis (4.6\%) and in 17 of the 275 analyzed during follow-up (6.2\%). A total of 4 patients in whom the IG translocation was identified at follow-up did not carry the translocation at diagnosis. The IG heavy locus $(I G H)$ was involved in 27 translocations (77.1\%), the IG $\kappa$ locus $(I G K)$ in $1(2.9 \%)$ and the IG $\lambda$ locus (IGL) in 7 (20.0\%). The chromosome band partners of the IG translocations were $18 \mathrm{q} 21$ in 16 cases $(45.7 \%), 11 \mathrm{q} 13$ and $19 \mathrm{q} 13$ in 4 cases each (11.4\% each), 8q24 in 3 cases (8.6\%), 7q21 in 2 cases $(5.7 \%)$, whereas 6 other bands were involved once $(2.9 \%$ each). At present, 35 partner chromosomal bands have been described, but the partner gene has solely been identified in 10 translocations. CLL associated with IG gene translocations is characterized by atypical cell morphology, including plasmacytoid characteristics, and the propensity of being enriched in prolymphocytes. The IG heavy chain variable region $(I G H V)$ mutational status varies between translocations, those with unmutated $I G H V$ presumably involving cells at an earlier stage of B-cell lineage. All the partner genes thus far identified are involved in the control of cell proliferation and/or apoptosis. The translocated partner gene becomes transcriptionally deregulated as a consequence of its transposition into the IG locus. With the exception of $\mathrm{t}(14 ; 18)(\mathrm{q} 32 ; \mathrm{q} 21)$ and its variants, prognosis appears to be poor for the other translocations.
\end{abstract}

Correspondence to: Professor Marc De Braekeleer, Department of Cytogenetics and Reproductive Biology, Morvan Hospital, Regional University Hospital Center of Brest (CHRU), 2 Foch Avenue, F-29609 Brest, France

E-mail: marc.debraekeleer@univ-brest.fr

Key words: immunoglobulin, translocation, chronic lymphocytic leukemia
Therefore, searching for translocations involving not only $I G H$, but also $I G L$ and $I G K$, by banding and molecular cytogenetics is required. Furthermore, it is important to identify the partner gene to ensure the patients receive the optimal treatment.

\section{Contents \\ 1. Introduction \\ 2. Brest University Hospital cohort \\ 3. Frequency and distribution of IG translocations \\ 4. Recurrent IG translocations with known partner genes \\ 5. IG translocation-associated CLL is heterogeneous}

\section{Introduction}

Reciprocal chromosomal translocations are recurrent features of several hematological malignancies (http://cgap.nci.nih. gov/Chromosomes/Mitelman; http://atlasgeneticsoncology. org/). The cloning of the genes located at the breakpoints of chromosomal translocations in leukemia and lymphoma has led to the identification of new genes involved in carcinogenesis. These rearrangements generate new genes, called fusion genes, or lead to the activation of a proto-oncogene by relocation near active regulatory sequences. The second mechanism is the hallmark of lymphoma and B-cell chronic lymphocytic leukemia (CLL).

CLL represents the most common hematological malignancy in Western countries, with a highly heterogeneous clinical course and prognosis, and a time-to-progression varying from months to several years. Some patients live for prolonged periods without therapy, while others rapidly develop progressive disease and require treatment $(1,2)$.

Morphologically, the World Health Organization recognizes 3 subtypes (3): The 'typical' CLL is characterized by small lymphocytes with mature chromatin and minimal cytoplasm without nucleoli, and $<10 \%$ of prolymphocytes (PLs). The prolymphocytic leukemia (PLL) has $>55 \%$ PLs, which are large cells with a round nucleus, a prominent vesicular nucleolus, condensed nuclear chromatin and abundant cytoplasm (4). Occasionally, a subset of CLL cases acquires an 
increased number (10-55\%) of PLs (CLL/PL) and eventually transforms to a neoplasm composed predominantly of PLs (5). The immunophenotype of CLL is $\mathrm{CD}^{+}, \mathrm{CD}^{2} 3^{+}, \mathrm{FMC7}^{-}$, CD20 $\mathrm{dim}^{+}$and clonal surface immunoglobulin (sIg) $\mathrm{dim}^{+}(6)$.

Transformation into a fast-growing diffuse large B-cell lymphoma is encountered in $\sim 5 \%$ of CLL patients and it is referred to as Richter's syndrome $(7,8)$. Under rare circumstances, plasmablastic lymphoma or plasmablastic transformation may be observed, representing an unusual example of Richter's syndrome.

Numerous studies have searched for reliable prognostic markers capable of predicting the progression and outcome of this disease. They include two different clinical staging systems, one described by Rai et al (9) and the other by Binet et al (10). Other prognostic markers, such as CD38 and ZAP-70 expression and IG heavy chain variable region $(I G H V)$ mutational status, are being evaluated or used $(2,11)$. More recently, next-generation sequencing has identified mutations in a few genes that may have a prognostic impact $(12,13)$.

At present, interphase fluorescent in situ hybridization (iFISH) targeting four chromosomal abnormalities [deletion of $13 \mathrm{q} 14$, trisomy 12 , deletion of $11 \mathrm{q} 22$ (ATM) and deletion of 17p13 (TP53)] remains the most effective outcome predictor (14). However, iFISH only provides a partial view of the karyotypic complexity of CLL; specific cytogenetic abnormalities, including translocations, which remain undetected by iFISH, are currently identified, due to the use of more effective B-cell mitogens. Among these, translocations involving the immunoglobulin (IG) genes have emerged as one of the cytogenetic abnormalities that have clinical and biological specificities and prognostic implications.

\section{Brest University Hospital cohort}

Patients. Between 2000 and 2014, the Cytogenetics Laboratory of the Brest University Hospital collected blood or bone marrow samples from CLL patients diagnosed and/or followed up in 10 hospitals in Brittany. The clinical diagnosis of CLL in each patient was based on a persistent lymphocytosis of $>5 \times 10^{9}$ cells $/ 1$ and a typical immunophenotypic picture $\left(\mathrm{CD}^{+}, \mathrm{CD}^{+} 9^{+}, \mathrm{CD} 20^{+}, \mathrm{CD} 23^{+}\right.$and weak expression of sIg) (15-17). A total of 396 patients were referred at diagnosis and 275 during follow-up.

Methods. Peripheral blood and bone marrow were cultured for $72 \mathrm{~h}$. Cell stimulation was performed with tetradecanoylphorbol acetate from 2000 to 2010, and with the immunostimulatory CpG-oligonucleotide DSP30 and interleukin-2 from 2010 onwards. The chromosomes were R-banded and the karyotype was described according to the International System for Human Cytogenetics Nomenclature (18).

iFISH was performed on fixed cells from the cultures using the Vysis CLL FISH Probe kit (Abbott Molecular, Rungis, France). The CLL panel includes two set of probes: A first set consisting of LSI TP53 SpectrumOrange and ATM SpectrumGreen probes, and a second set consisting of LSI D13S319 SpectrumOrange/13q34 SpectrumAqua and CEP 12 SpectrumGreen probes. A total of 300 interphase nuclei were studied for each set of probes. Based on the recommendations of the CLL Research Consortium FISH standardization project, FISH cut-off was set at $10 \%$ for each hybridization (19).

Metaphase and iFISH using the IGH Breakapart Probe (Cytocell, Compiègne, France or Abbott Molecular) was not systematically performed on all samples, but only on those in which an abnormality of chromosome 14 was suspected. Translocations involving the IG $\kappa$ locus $(I G K)$ or IG $\lambda$ locus (IGL) genes were assessed with the IGK Breakapart Probe or the IGL Breakapart Probe (Cytocell).

Results. Overall, an IG translocation was identified in 35 patients (Table I). The patients included 22 men and 13 women. The mean age was 72 years (range, $40.8-85$ years; standard deviation, 8.5 years) and the median age was 72.3 years. The patient sample included 18 patients among the 396 investigated at diagnosis (4.6\%) and 17 of the 275 analyzed during follow-up (6.2\%). An IG translocation was present at diagnosis and follow-up in 3 patients. A total of 4 patients for whom the IG translocation was identified at follow-up did not carry the translocation at diagnosis, while no metaphases were observed at diagnosis in another patient.

IG heavy locus ( $I G H$; chromosome band 14q32) was involved in 27 (77.1\%), IGK (band 2p11) in $1(2.9 \%)$ and $I G L$ (band 22q11) in $7(20.0 \%)$ translocations. The chromosome band partners of the IG translocations were $18 \mathrm{q} 21$ in 16 cases (45.7\%), 11q13 and 19q13 in 4 cases each (11.4\% each), 8q24 in 3 cases $(8.6 \%)$ and $7 q 21$ in 2 cases $(5.7 \%)$, whereas 6 other bands were involved once ( $2.9 \%$ each). However, as rearrangements involving $I G H$ were not systematically searched for by FISH, we cannot exclude that some cryptic translocations may have escaped detection.

iFISH with the CLL FISH Probe kit was performed on 25 patients carrying an IG translocation (Table II). Mono-allelic deletion of 13 q14 was identified in 9 patients (36\%), including a bi-allelic in 2 patients. Trisomy 12 was found in 12 patients (48\%). Deletions of $11 \mathrm{q} 22$ and $17 \mathrm{p} 13$ were observed in $1(4 \%)$ and $3(12 \%)$ patients, respectively (Table II). Recently, we reported our iFISH results on 638 patients. $\operatorname{Del}(13 q 14)$ was found in $65 \%$ and a trisomy 12 in $22.1 \%$ of the patients. Deletions of 11q22 and 17p13 were observed in 13.3 and $8.6 \%$ of the patients, respectively (20).

\section{Frequency and distribution of IG translocations}

For years, banding karyotyping has been hampered by the low mitotic index of CLL cells, and the majority of the studies currently rely on iFISH with an IGH probe to determine the frequency of $I G H$ translocations. A total of 18 studies were retrieved from the literature (Table III). The overall frequency was $8.3 \%(327 / 3,922)$ but the range varied considerably, from $1.9 \%$ in a study from the USA, to $26.1 \%$ in a Canadian study. Although a geographic/ethnic uneven distribution cannot be ruled out, it is likely that differences in diagnosis (PLL included or not), referral, access to care and healthcare systems may have affected the frequency. Even for those investigated at diagnosis, we cannot exclude that socioeconomic status or access to healthcare may have delayed the time at which diagnosis was made, with the consequence that patients in some series were at a more advanced stage $(20,21)$. 
Table I. Demographic data and karyotype of 35 patients with an IG translocation (Brest cohort).

Age

Patient Gender (years) Evolution
Karyotype

\begin{tabular}{|c|c|c|c|c|}
\hline 1 & M & 79.1 & $\mathrm{E}$ & $\begin{array}{l}\text { 46,XY,del(11)(q21q23)[4]/46,idem,add(17)(p11)[6]/46,idem,t(3;14)(q21;q32)[6]/ } \\
\text { 46,idem,add(13)(q14),add(17)(p11)[2]/46,idem,del(17)(p11)[2]/46,XY[1] }\end{array}$ \\
\hline 2 & M & 62.7 & $\mathrm{D}$ & $47, X Y,+12, t(14 ; 18)(q 32 ; q 21)[22]$ \\
\hline 3 & M & 65.4 & $\mathrm{E}$ & 46,XY,t(7;22)(q21;q11),add(13)(p11)[11]/46,XY[8] \\
\hline 4 & $\mathrm{~F}$ & 74.4 & $\mathrm{D}$ & $\begin{array}{l}45, \mathrm{XX}, \operatorname{add}(3)(\mathrm{q} 27), \operatorname{der}(8) \mathrm{t}(8 ; 12)(\mathrm{p} 11 ; \mathrm{q} 11), \mathrm{t}(11 ; 14)(\mathrm{q} 13 ; \mathrm{q} 32),-12, \operatorname{del}(17) \\
(\mathrm{p} 1 ? 2),-17,+ \text { mar1 } 1, \text { avec variations }[17] / 46, \mathrm{XX}[4]\end{array}$ \\
\hline 5 & M & 62.9 & $\mathrm{E}$ & $\begin{array}{l}47, X Y,+12[16] / 47, s 1, \operatorname{del}(13)(q 13 q q 21)[4] / 47, s 12, t(9 ; 14)(q 13 ; q 32)[2] / \\
47, \operatorname{sl} 3, \operatorname{add}(11)(q 21)[2]\end{array}$ \\
\hline 6 & M & 78.8 & $\mathrm{D}$ & 47,XY,t(10;17)(q21;q22),t(14;19)(q32;q13),del(14)(q23q32),+21[5]/46,XY[18] \\
\hline 6 & M & 79.0 & $\mathrm{E}$ & 47,XY,t(10;17)(q21;q22),t(14;19)(q32;q13),del(14)(q23q32),+21[7]/46,XY[18] \\
\hline 7 & M & 72.0 & $\mathrm{D}$ & $48, X Y,+4, t(11 ; 14)(q 13 ; q 32),+12,[15] / 46, X Y[6]$ \\
\hline 8 & $\mathrm{~F}$ & 71.8 & $\mathrm{E}$ & $48, \mathrm{XXX},+12, \mathrm{t}(18 ; 22)(\mathrm{q} 21 ; \mathrm{q} 11)[6] / 46, \mathrm{XX}[15]$ \\
\hline 8 & $\mathrm{~F}$ & 81.7 & $\mathrm{E}$ & $48, X X,+X,+12, t(18 ; 22)(q 21 ; q 11)[16] / 46, X X[6]$ \\
\hline 9 & M & 78.3 & $\mathrm{E}$ & $\begin{array}{l}48, X Y,+8, \operatorname{dup}(12 \mathrm{q}) \times 2, \operatorname{add}(13)(\mathrm{q} 34), \mathrm{t}(14 ; 18)(\mathrm{q} 32 ; \mathrm{q} 21),+20[16] / 50, \mathrm{sl},+\mathrm{X},+7[2] / 50, \mathrm{sdl} 1, \\
(\mathrm{p} 13)[4] / 46, \mathrm{XY}[1]\end{array}$ \\
\hline 10 & M & 76.0 & $\mathrm{D}$ & 46,XY,t(14;18)(q32;q21)[5]/47,idem,+12[1]/46,XY[16] \\
\hline 11 & M & 73.7 & $\mathrm{D}$ & 46,XY,t(14;18)(q32;q21)[6]/47,idem,+12[3]/46,XY[13] \\
\hline 12 & M & 78.1 & $\mathrm{E}$ & $46, X Y, t(14 ; 18)(q 32 ; q 21)[23]$ \\
\hline 13 & M & 69.7 & $\mathrm{D}$ & $47, X Y,+12, t(14 ; 18)(q 32 ; q 21)[4] / 46, X Y[18]$ \\
\hline 14 & $\mathrm{~F}$ & 79.6 & $\mathrm{D}$ & $47, \mathrm{XX}, \mathrm{t}(1 ; 14)(\mathrm{p} 11 ; \mathrm{q} 32),+12[7] / 46, \mathrm{XX}[14]$ \\
\hline 15 & $\mathrm{~F}$ & 71.3 & $\mathrm{E}$ & $47, X X,+12, t(18 ; 22)(q 21 ; q 11)$ \\
\hline 15 & $\mathrm{~F}$ & 71.8 & $\mathrm{E}$ & $47, \mathrm{XX},+12, \mathrm{t}(18 ; 22)(\mathrm{q} 21 ; \mathrm{q} 11)[6] / 47, \mathrm{idem}, \mathrm{t}(1 ; 16)(\mathrm{p} 10 ? \mathrm{q} 10)[2] / 46, \mathrm{XX}[14]$ \\
\hline 16 & M & 81.4 & $\mathrm{E}$ & $\begin{array}{l}48, X Y,+3, \operatorname{del}(10)(q 2 ? 4), \operatorname{del}(13 q), \operatorname{ins}(13 ; ?)(q 14 ; ?),+18[4] / 48, \text { idem,t(4;14) } \\
(q 2 ? 1 ; q 32[1] / 46, X Y[18]\end{array}$ \\
\hline 17 & M & 81.2 & $\mathrm{E}$ & 46,XY,del(13q),add(18p)[1]/46,XY,t(11;14)(q13;q32)[1]/46,XY[25] \\
\hline 18 & $\mathrm{~F}$ & 68.5 & $\mathrm{D}$ & $47, X X,+12, t(14 ; 18)(q 32 ; q 21)[5] / 46, X X[2]$ \\
\hline 18 & $\mathrm{~F}$ & 70.7 & $\mathrm{E}$ & $47, \mathrm{XX},+12, \mathrm{t}(14 ; 18)(\mathrm{q} 32 ; \mathrm{q} 21)[17] / 46, \mathrm{XX}[5]$ \\
\hline 19 & M & 72.3 & $\mathrm{E}$ & $46, X,-Y, t(11 ; 14)(q 13 ; q 32), \operatorname{del}(11)(q 22),+\operatorname{mar} 1[7] / 46, X Y[17]$ \\
\hline 20 & M & 76.6 & $\mathrm{D}$ & $47, X Y,+12[16] / 47$, idem $, t(14 ; 19)(q 32 ; q 13)[3] / 46, X Y[1]$ \\
\hline 21 & $\mathrm{~F}$ & 84.1 & $\mathrm{D}$ & $46, \mathrm{XX}, \mathrm{t}(14 ; 22)(\mathrm{q} 32 ; \mathrm{q} 11)[2] / 46, \mathrm{XX}[33]$ \\
\hline 22 & M & 81.4 & $\mathrm{D}$ & $47, X Y,+12, t(14 ; 18)(q 32 ; q 21)[12] / 47, \operatorname{idem}, \operatorname{del}(6)(q 12 q 16)[8] / 46, X Y[1]$ \\
\hline 23 & $\mathrm{~F}$ & 75.7 & $\mathrm{E}$ & 46,XX, add(3)(q22), der(8)t(8;14)(q24;q32), del(10)(q2?5), del(13)(q13q31), add(14)(q32) \\
\hline 24 & M & 85.0 & $\mathrm{E}$ & 46,XY,del(1)(p34)[13]/45,sl,t(8;14)(q24;q32)[3]/46,sdl1,del(11)(q21)[3]/46,XY[2] \\
\hline 25 & $\mathrm{~F}$ & 74.2 & $\mathrm{D}$ & $47, X X,+12, t(14 ; 19)(q 32 ; q 13)[18] / 47, \operatorname{idem}, \operatorname{del}(12)(q 23)[2] / 46, X X[2]$ \\
\hline 26 & M & 54.0 & $\mathrm{D}$ & 47,XY,+12[5]/47,idem,t(14;18)(q32;q21)[8]/47,idem,add(17)(q2?5)[8]/46,XY[1] \\
\hline 27 & $\mathrm{~F}$ & 65.5 & $\mathrm{D}$ & $46, X X, t(14 ; 18)(q 32 ; q 21)[12] / 46, X X[7]$ \\
\hline 27 & $\mathrm{~F}$ & 75.4 & $\mathrm{E}$ & $46, X X, t(14 ; 18)(q 32 ; q 21)[5] / 46, X X[3]$ \\
\hline 28 & M & 67.9 & $\mathrm{E}$ & 45,X,-Y[6]/47,XY,+12[2]/47,idem,t(6;14)(p21;q32)[7]/46,XY[6] \\
\hline 29 & $\mathrm{~F}$ & 66.5 & $\mathrm{D}$ & $47, X X,+12[2] / 47, X X,+12, t(18 ; 22)(q 21 ; q 11)[5] / 50, X X,+3,+12,+17,+18[2] / 46, X X[10]$ \\
\hline 30 & M & 61.9 & $\mathrm{E}$ & 46,XY,t(18;22)(q21;q11)[6]/46,XY,del(13)(q13;q21),t(18;22)(q21;q11)[12]/46,XY[2] \\
\hline 30 & M & 66.5 & $\mathrm{E}$ & $\begin{array}{l}\text { 46,XY,t(18;22)(q21;q11)[7]/46,idem,del(13)(q13q21)[13]/46,XY,t(7;13) } \\
(\mathrm{p} 2 ; \mathrm{q} 14), t(8 ; 13) \\
(\mathrm{p} 23 ; \mathrm{q} 14), \mathrm{t}(18 ; 22)(\mathrm{q} 21 ; \mathrm{q} 11)[2]\end{array}$ \\
\hline 31 & $\mathrm{~F}$ & 40.8 & $\mathrm{D}$ & $46, X X, t(14 ; 19)(q 32 ; q 13)[17] / 46, X X[1]$ \\
\hline 32 & M & 70.1 & $\mathrm{E}$ & $46, X Y, t(8 ; 22)(q 24 ; q 11)[22]$ \\
\hline 33 & M & 59.9 & $\mathrm{E}$ & $46, X Y, t(18 ; 22)(q 21 ; q 11)[19] / 46, X Y[1]$ \\
\hline 34 & $\mathrm{~F}$ & 78.9 & $\mathrm{E}$ & $\begin{array}{l}\text { 46,XX,del(5)(q1?4q2?3)[15]/45,idem,-4,del(4)(p1?3),der(11) } \\
(11 \text { pter->11p12::?::11cen->11q22::?)[4]/46,idem,t(14;18)(q32;q21)[2] }\end{array}$ \\
\hline 35 & $\mathrm{~F}$ & 69.0 & $\mathrm{D}$ & $47, \mathrm{XX},+12[12] / 46, \mathrm{XX}, \mathrm{t}(2 ; 7)(\mathrm{p} 11 ; \mathrm{q} 21)[2] / 46, \mathrm{XX}[10]$ \\
\hline
\end{tabular}

IG, immunoglobulin; M, male; F, female; E, during follow-up; D, at diagnosis. 
Table II. iFISH results of 35 patients with an IG translocation (Brest cohort).

\begin{tabular}{|c|c|c|c|c|c|}
\hline \multirow[b]{2}{*}{ Patients } & \multicolumn{5}{|c|}{ iFISH } \\
\hline & $13 \mathrm{q} 14$ & bi13q14 & +12 & ATM & p53 \\
\hline 1 & $+/-$ & & $\mathrm{N}$ & $+/-$ & $+/-$ \\
\hline \multicolumn{6}{|l|}{2} \\
\hline 3 & $+/+$ & $+/+$ & $\mathrm{N}$ & $+/+$ & $+/-$ \\
\hline 4 & $+/+$ & $+/+$ & + & $+/+$ & $+/-$ \\
\hline \multicolumn{6}{|l|}{5} \\
\hline \multicolumn{6}{|l|}{6} \\
\hline \multicolumn{6}{|l|}{6} \\
\hline \multicolumn{6}{|l|}{7} \\
\hline \multicolumn{6}{|l|}{8} \\
\hline 8 & $+/+$ & $+/+$ & + & $+/+$ & $+/+$ \\
\hline \multicolumn{6}{|l|}{9} \\
\hline 10 & $+/+$ & $+/+$ & + & $+/+$ & $+/+$ \\
\hline 11 & $+/+$ & $+/+$ & + & $+/+$ & $+/+$ \\
\hline 12 & $+/-$ & $+/+$ & $\mathrm{N}$ & $+/+$ & $+/+$ \\
\hline 13 & $+/+$ & $+/+$ & + & $+/+$ & $+/+$ \\
\hline 14 & $+/+$ & $+/+$ & + & $+/+$ & $+/+$ \\
\hline 15 & $+/+$ & $+/+$ & + & $+/+$ & $+/+$ \\
\hline 15 & $+/+$ & $+/+$ & + & $+/+$ & $+/+$ \\
\hline \multicolumn{6}{|l|}{16} \\
\hline 17 & $+/-$ & $+/+$ & $\mathrm{N}$ & $+/+$ & $+/+$ \\
\hline 18 & $+/+$ & $+/+$ & + & $+/+$ & $+/+$ \\
\hline 18 & $+/+$ & $+/+$ & + & $+/+$ & $+/+$ \\
\hline \multicolumn{6}{|l|}{19} \\
\hline 20 & $+/+$ & $+/+$ & + & $+/+$ & $+/+$ \\
\hline 21 & $+/+$ & $+/+$ & $\mathrm{N}$ & $+/+$ & $+/+$ \\
\hline \multicolumn{6}{|l|}{22} \\
\hline 23 & $+/-$ & $+/+$ & $\mathrm{N}$ & $+/+$ & $+/+$ \\
\hline 24 & $+/+$ & $+/+$ & $\mathrm{N}$ & $+/+$ & $+/+$ \\
\hline 25 & $+/+$ & $+/+$ & + & $+/+$ & $+/+$ \\
\hline 26 & $+/+$ & $+/+$ & + & $+/+$ & $+/+$ \\
\hline \multicolumn{6}{|l|}{27} \\
\hline 27 & $+/-$ & $+/+$ & $\mathrm{N}$ & $+/+$ & $+/+$ \\
\hline 28 & $+/-$ & $-/-$ & + & $+/+$ & $+/+$ \\
\hline \multicolumn{6}{|l|}{29} \\
\hline 30 & $+/-$ & $-/-$ & $\mathrm{N}$ & $+/+$ & $+/+$ \\
\hline 30 & $+/-$ & $-/-$ & $\mathrm{N}$ & $+/+$ & $+/+$ \\
\hline 31 & $+/+$ & $+/+$ & $\mathrm{N}$ & $+/+$ & $+/+$ \\
\hline 32 & $+/+$ & $+/+$ & $\mathrm{N}$ & $+/+$ & $+/+$ \\
\hline 33 & $+/-$ & $+/+$ & $\mathrm{N}$ & $+/+$ & $+/+$ \\
\hline 34 & $+/-$ & $+/+$ & $\mathrm{N}$ & $+/+$ & $+/+$ \\
\hline 35 & & & & & \\
\hline
\end{tabular}

iFISH, interphase fluorescent in situ hybridization; IG, immunoglobulin; +/+, normal; +/-, monoallelic deletion; -/-, biallelic deletion; $\mathrm{N}$, normal; 13q14, del(13q14); ATM, del(11q22); p53, del(17p13). Certain patients were studied at diagnosis and during follow-up; thus, they may appear twice.
Table III. Frequency of translocations involving IGH detected by iFISH.

\begin{tabular}{lcccc}
\hline $\begin{array}{l}\text { First } \\
\begin{array}{l}\text { Author/ } \\
\text { (Refs.) }\end{array}\end{array}$ & Country & $\begin{array}{l}\text { No. of } \\
\text { patients }\end{array}$ & $\begin{array}{l}\text { No. of } \\
\text { patients } \\
\text { with IGHt }\end{array}$ & $\begin{array}{c}\text { Frequency } \\
\text { of IGHt } \\
(\%)\end{array}$ \\
\hline Gerrie (133) & Canada & 290 & 27 & 9.3 \\
Gerrie (132) & Canada & 142 & 37 & 26.1 \\
Lu (134) & USA & 149 & 23 & 15.4 \\
Shanafelt (135) & USA & 159 & 3 & 1.9 \\
Aoun (136) & USA & 58 & 10 & 17.2 \\
Nelson (137) & USA & 109 & 10 & 9.2 \\
Flanagan (138) & USA & 42 & 8 & 19.0 \\
Jenderny (139) & Germany & 129 & 4 & 3.1 \\
Haferlach (140) & Germany & 500 & 30 & 6.0 \\
Jeromin (13) & Germany & 1,158 & $57^{\text {a }}$ & 4.9 \\
Alhourani (141) & Germany & 85 & 3 & 3.5 \\
Döhner (142) & Germany & 325 & 12 & 3.7 \\
Berkova (143) & Czech & 146 & 11 & 7.5 \\
& Republic & & & \\
Amare (144) & India & 116 & 7 & 6.0 \\
Yoon (145) & South & 48 & 6 & 12.5 \\
& Korea & & & \\
Xu (146) & China & 83 & 8 & 9.6 \\
Qiu (147) & China & 143 & 28 & 19.6 \\
Wang (148) & China & 240 & 43 & 17.9 \\
\hline
\end{tabular}

${ }^{a}$ Including IGH deletions. IGH, immunoglobulin H; iFISH, interphase fluorescent in situ hybridization; IGHt, translocations involving IGH.

A limited number of studies attempted to identify the partner genes. Even in those cases, they used commercially available Dual Color, Dual Fusion Translocation Probes to detect $I G H / \mathrm{B}-$ cell lymphoma 2 (BCL2), IGH/cyclin D1 (CCND1), sometimes completed by v-myc avian myelocytomatosis viral oncogene homolog $(M Y C)$ and BCL3 Dual Color Breakapart rearrangement probes. Furthermore, none of these studies used probes targeting the $I G K$ and $I G L$ genes and, therefore, underestimated the true frequency of IG translocations.

We conducted a thorough search in the literature looking for IG translocations, using the Mitelman Database of Chromosome Aberrations and Gene Fusions in Cancer (http://cgap.nci.nih. gov/Chromosomes/Mitelman) as the starting point.

Some translocations have been found to be frequent, while others have only been reported in a few or single cases. At present, 31 partner chromosome bands have been described, but the partner gene has only been identified in 10 translocations. We identified 4 chromosomal bands that had never been shown to be involved in IG translocations among the 35 patients in the Brest cohort, bringing the total to 35 (Fig. 1). The number of bands involved in IG translocations is significantly lower compared with that involved in Ets variant 6 or Runt-related transcription factor 1 gene translocations (48 and 55 bands, respectively) $(22,23)$. The difference is likely the result of the B-cell lineage specificity of the partner genes deregulated by the IG translocations. 

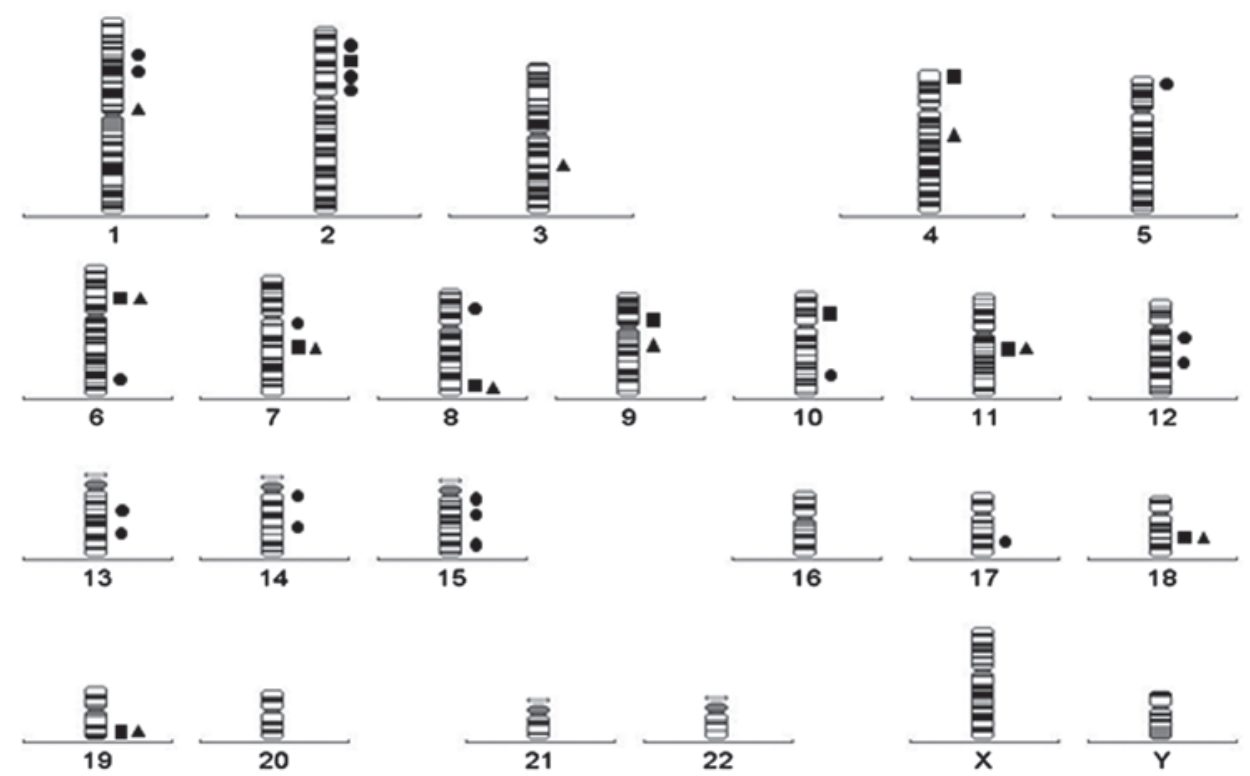

Figure 1. Distribution of the chromosomal band partners of immunoglobulin gene translocations. Squares, translocations with known partner gene; circles, translocations with unknown partner gene; triangles, translocations with unknown partner gene identified in Brest.

\section{Recurrent IG translocations with known partner genes}

As previously mentioned, IG translocations relocate genes near active regulatory sequences, leading to their overexpression. However, two exceptions are known. In 2004, Schmidt et al (24) reported a patient with B-cell CLL carrying a t(12;14)(q23;q32), in whom the carbohydrate (chondroitin 4) sulfotransferase 11 gene (CHST11) was fused to $I G H$ to create a chimeric gene. Fusion RNAs may be translated into truncated proteins and lead to deregulation of the CHST11 protein trafficking across intracellular membranes, resulting in loss of function, as observed with other fusions (23).

A $\mathrm{t}(14 ; 22)(\mathrm{q} 32 ; \mathrm{q} 11)$ involving the $I G H$ and $I G L$ genes was retrieved from the literature (25) and another was identified in our series (patient 21). Although the mechanism of neoplastic transformation remains unknown, one cannot exclude that a nearby gene may be involved. Indeed, the $B C L 11 B$ (zinc finger protein) gene, closely related to $B C L 11 \mathrm{~A}$ involved in $\mathrm{t}(2 ; 14)(\mathrm{p} 16 ; \mathrm{q} 32)$, may be deregulated, although it is located $6.3 \mathrm{Mb}$ from the $I G H$ locus. It was suggested that $B C L 11 B$ acted as a transcriptional repressor as well as an activator in a context-dependent manner and may function on the P53 signaling pathway $(26,27)$.

t(14;18)(q32;q21) and variants (IGH/BCL2). All 3 translocations, $\mathrm{t}(14 ; 18)(\mathrm{q} 32 ; \mathrm{q} 21), \mathrm{t}(2 ; 18)(\mathrm{p} 11 ; \mathrm{q} 21.3)$ and $\mathrm{t}(18 ; 22)$ (q21.3;q11), and their molecular consequences, IGH/BCL2, $I G K / B C L 2$ and $I G L / B C L 2$, have been reported $(28,29)$. These translocations are present at diagnosis or arise during evolution and are usually associated with additional karyotypic changes, more particularly with trisomy 12 (30-32).

A total of 144 cases reported in the literature were reviewed. A t $(14 ; 18)$ was identified in 111 cases $(77.1 \%)$, a t $(2 ; 18)$ in 8 cases $(5.5 \%)$ and a t $(18 ; 22)$ in 25 cases (17.4\%). Trisomy 12 was found in 71 cases (49.3\%). The IG translocation was the sole abnormality in 39 cases $(27.1 \%)$ and part of a complex karyotype (defined as composed of $\geq 3$ abnormalities) in 37 cases (25.7\%).
These are found in typical CLL (sometimes during Richter's transformation) and in CLL/PL (29,30,32). Atypical cytological characteristics (increased number of lymphoid cells with irregular nuclear contour, plasmacytoid features or PLs) and/or immunophenotypic profile (lack of CD23 and intermediate/strong CD20 expression) is reported and hypothesized to be linked to trisomy $12(29,33,34)$. IG/BCL2 fusion is significantly associated with mutated $I G H V$ status (30-32), which led Baseggio et al (30) to conclude at a post-germinal center cellular origin.

There is persisting controversy regarding the prognostic impact of $I G / B C L 2$, being considered as poor by certain authors (31), while others found that the clinical course was not affected $(30,32)$.

The $\mathrm{t}(14 ; 18)(\mathrm{q} 32 ; \mathrm{q} 21)$ and its variants lead to the overexpression of the $B C L 2$ gene $(35,36)$. This gene encodes an integral outer mitochondrial membrane protein that blocks the apoptotic death of some cells, such as lymphocytes $(37,38)$.

$t(14 ; 19)(q 32 ; q 13)(I G H / B C L 3)$. This translocation appears at diagnosis in the primary clone in the majority of the cases, and as a secondary change during karyotypic progression in a limited number of cases (39). This is rarely the sole cytogenetic aberration, with trisomy 12 being the most frequent associated abnormality (40-45).

A total of 123 cases reported in the literature were reviewed. No variant translocation was found. Trisomy 12 was identified in 72 cases $(58.5 \%)$. The translocation was the sole abnormality in 13 cases (10.6\%) and part of a complex karyotype in 52 cases $(42.3 \%)$.

A high proportion of patients with CLL and $t(14 ; 19)$ are aged $<40$ years (40-44) and the median age is significantly lower compared with that observed in non-carriers (20).

CLL with $\mathrm{t}(14 ; 19)$ is associated with atypical morphological (small cells, often with nuclear indentations) and immunophenotypical characteristics $(40,41,46)$. The translocation is found in all three subtypes and during 
Richter's transformation $(42,43,45,47)$. The vast majority of $\mathrm{t}(14 ; 19)$ express unmutated $I G H V$ genes $(39-41,45,46)$, which is significantly higher compared with the $46 \%$ reported in the literature for typical CLL (48). Patients have an aggressive clinical course and the overall prognosis is poor $(42,43,45,46)$.

The $\mathrm{t}(14 ; 19)(\mathrm{q} 32 ; \mathrm{q} 13)$ and its variants lead to the overexpression of the BCL3 gene (49). This gene encodes a protein that is a member of the I $\mathrm{I} \mathrm{B}$ family and is present predominantly in the nucleus. It contributes to the regulation of transcriptional activation of nuclear factor- $\kappa \mathrm{B}$ target genes and to the regulation of cell proliferation. It binds to the promoter of $C C N D 1$, thus stimulating gene transcription, and inhibits P53-induced apoptosis (50-55).

$t(11 ; 14)(q 13 ; q 32) t(11 ; 22)(q 13 ; q 11)(I G H / C C N D 1)$. Although the $(11 ; 14)(\mathrm{q} 13 ; \mathrm{q} 32)$ translocation was previously considered to be the hallmark of mantle cell lymphoma (MCL), it is currently identified in $10-20 \%$ of PLL and $2-5 \%$ of CLL cases (56). CLL cases in which this translocation has been found are usually atypical in terms of morphology (majority of small lymphocytes with PLs and/or large lymphocytes) and immunophenotype $\left(\mathrm{CD}^{+}, \mathrm{CD}^{+}{ }^{+}, \mathrm{SIg}^{+}, \mathrm{FMC}^{+}\right.$and $\left.\mathrm{CD} 10^{-}\right)$(57-60). Recognition of this cytogenetic subset of atypical CLL is crucial, as, given its poor prognosis, it may require early treatment (61).

We identified 106 CLL or PLL cases associated with $\mathrm{t}(11 ; 14)$ in the literature. Only one variant translocation, $\mathrm{t}(11 ; 22)$ (q13;q11), was found (62). Trisomy 12 was identified in 5 cases $(4.7 \%)$. The translocation was the sole abnormality in 21 cases (19.6\%) and part of a complex karyotype in 64 cases $(59.8 \%)$.

Although $\mathrm{t}(11 ; 14)$ is usually present at diagnosis, Nishida et al (63) reported a patient with CLL associated with trisomy 12 and $t(14 ; 19)(q 32 ; q 13)$ at diagnosis, who developed a $\mathrm{t}(11 ; 14)(\mathrm{q} 13 ; \mathrm{q} 32)$ at relapse.

Distinction of $\mathrm{t}(11 ; 14)$ translocation-associated CLL and MCL in the leukemic phase is not unequivocal $(60,64)$. It is hypothesized that MCL and atypical CLL with the $t(11 ; 14)$ represent the extremes of a spectrum of disorders of follicle mantle lineage (60).

The $\mathrm{t}(11 ; 14)(\mathrm{q} 13 ; \mathrm{q} 32)$ leads to the overexpression of the CCND1 gene (65). The protein encoded by this gene belongs to the highly conserved cyclin family. It interacts with the cyclin-D-dependent kinases (CDK) 4 and 6 that phosphorylate the retinoblastoma 1 (RB1) tumor suppressor, thus regulating a process that promotes the $\mathrm{G} 1 / \mathrm{S}$ cell cycle transition $(66,67)$.

$t(8 ; 14)(q 24 ; q 32)$ and variants $(I G H / M Y C)$. This abnormality is rare in typical CLL and is associated with increased PLs (CLL with occasional PLs, CLL/PL and PLL) (68-71). Male and elderly patients are predominantly affected, as in CLL/PL patients (69-71).

This translocation may be acquired in the chronic phase, but is associated with an advanced clinical stage at presentation $(68,71)$. It is usually included in a complex karyotype. It may represent a secondary abnormality contributing to disease progression and carries a poor prognosis (68-70).

We reviewed 38 cases from the literature. A $\mathrm{t}(8 ; 14)$ was identified in 22 cases $(57.9 \%)$, a $\mathrm{t}(2 ; 8)$ in 5 cases $(13.2 \%)$ and a $\mathrm{t}(8 ; 22)$ in 11 cases $(28.9 \%)$. Trisomy 12 was rarely associated, being identified in only 3 cases (7.9\%). The IG translocation was the sole abnormality in 8 cases $(21.1 \%)$ and part of a complex karyotype in 18 cases (47.4\%).

Put et al (70) reported a prevalence of $\operatorname{del}(11)(\mathrm{q} 22)$ and $\operatorname{del}(17)(\mathrm{p} 13)$ in a cohort of 25 patients with a $t(8 ; 14)$ or variants, which was higher compared with that reported in CLL [6/25 (24\%); and 7/25 (28\%), respectively] (70).

The $\mathrm{t}(8 ; 14)(\mathrm{q} 24 ; \mathrm{q} 32)$ and its variants lead to the overexpression of the MYC gene (72). MYC is a transcription factor that controls functions associated with cell cycle progression, growth, differentiation, apoptosis, survival and metabolism. It functions as a transcription factor that regulates transcription of $>15 \%$ of all genes. MYC positively affects cell cycle regulation, apoptosis and metabolism, but negatively affects cellular differentiation and cell adhesion. Therefore, aberrant $M Y C$ expression deregulates the balance between survival and apoptosis signals at several different stages (73-76).

$t(2 ; 14)(p 16 ; q 32) I G H / B C L 11 A$. This rare but recurrent translocation affects young adults, even children $(77,78)$. Morphologically, the disease is characterized by a mixture of small and larger lymphocytes with indented and irregular nuclear contours, also including plasmacytoid lymphocytes and PLs. The immunophenotype is almost always typical of CLL (78).

The $(2 ; 14)$ translocation appears to be an early event, as it has been found to be the sole karyotypic abnormality at diagnosis. It is also present in the main clone, with subclones containing additional abnormalities in other patients $(77,78)$. Only 6 cases were retrieved from the literature, 2 of which were associated with trisomy 12, and 3 of which were present in subclones with a complex karyotype.

All patients thus far analyzed express ZAP-70 and all but one also carried unmutated $I G V H$ genes $(78,79)$. Therefore, it is expected that $\mathrm{t}(2 ; 14)$ is associated with an aggressive disease and a poor prognosis, which appears to be the case, although data is sparse $(77,78)$.

The $\mathrm{t}(2 ; 14)(\mathrm{p} 16 ; \mathrm{q} 32)$ leads to the overexpression of the $B C L 11 A$ gene (77). BCL11A encodes a zinc finger protein that interacts directly with BCL6; it is essential for the early lineage commitment steps in lymphopoiesis and functions in the development of $\mathrm{T}$ as well as B cells $(77,80)$. The BCL11A protein is expressed in the germinal centers and mantle zones of the lymph nodes $(80,81)$.

$t(10 ; 14)(p 12 ; q 32) t(10 ; 22)(p 12 ; q 11)$ [IGH/BMI1 proto-oncogene, polycomb ring finger $(B M I 1)]$. The $\mathrm{t}(10 ; 14)(\mathrm{p} 11-\mathrm{p} 13 ; \mathrm{q} 32)$ and $\mathrm{t}(10 ; 22)(\mathrm{p} 12 ; \mathrm{q} 11)$ were identified in 5 and 1 CLL cases, respectively (82). The translocation was identified during clinical progression or Richter's transformation and appears to carry a poor prognosis (82).

These translocations are not associated with a particular subtype of CLL, or with $I G V H$ mutation status; they do not appear to be driver abnormalities in CLL genesis, but are rather a marker of disease progression (82).

The $\mathrm{t}(10 ; 14)(\mathrm{p} 12 ; \mathrm{q} 32)$ and variants lead to the overexpression of the BMII proto-oncogene (82). This gene encodes a protein containing a conserved RING finger and a helix-turn-helix motif (83). The BMI1 protein is a core subunit of the PRC1 complex, which plays important roles 
in the regulation of $H O X$ gene expression $(84,85)$. BMI1 regulates the proliferation activity of normal cells, stem cells and progenitor cells, and plays a role in cell cycle checkpoints and progression, DNA damage repair, cell fate and differentiation, apoptosis and senescence $(86,87)$. BMI acts as transcriptional repressor of the cyclin-dependent kinase inhibitor $2 \mathrm{~A}$ gene $(C D K N 2 A)$, also referred to as $I N K 4 A$ or $A R F$ gene $(88,89)$.

t(4;14) (p16;q32) t(4;22)(p16;q11) [IGH/fibroblast growth factor receptor 3 (FGFR3)-multiple myeloma SET domain (MMSET)]. Although the $\mathrm{t}(4 ; 14)$ has long been known to be a recurrent abnormality in multiple myeloma, it was first described by Bacher et al (90) in 2 patients exhibiting the immunophenotype of CLL and CLL/PL. Cerny et al (91) reported a CLL patient with the $\mathrm{t}(4 ; 22)(\mathrm{p} 16 ; \mathrm{q} 11)$ and a typical immunophenotype, in whom the lymphoid proliferation was composed of small lymphocytes (with round nuclei, condensed chromatin, indistinct nucleoli and scant cytoplasm) and PLs (larger nucleolated lymphocytes). A fourth case was reported by Geller et al (92) in a patient with CLL/PL and a typical immunophenotype. A total of 2 cases had a trisomy 12 .

These 4 patients exhibited no consistent characteristics, other than the presence of PLs. The translocation was identified at diagnosis or during evolution. The cells were negative or positive for CD38 and ZAP-70, and had a mutated or non-mutated $I G V H$ status. Although the number of cases reported is small, this translocation should be considered as indicative of adverse prognosis.

The $\mathrm{t}(4 ; 14)(\mathrm{p} 16 ; \mathrm{q} 32)$ is a unique example of IG translocation, as it simultaneously deregulates 2 genes with oncogenic potential. Indeed, MMSET domain (also referred to as Wolf-Hirschhorn syndrome candidate 1) and FGFR3 reside on either side of the 4 p16 breakpoint. After the translocation, MMSET remains on the derivative chromosome 4, while FGFR3 moves to the derivative chromosome 14 (93-95). The MMSET protein has histone methyltransferase activity and may act as a transcriptional regulator controlling cell cycle and apoptosis $(96,97)$. The FGFR 3 protein is a tyrosine protein kinase that acts as a cell surface receptor for fibroblast growth factors and triggers downstream mitogen-activated protein kinase and phosphatidylinositol 3-kinase signaling. It plays an essential role in the regulation of cell growth and differentiation $(98,99)$.

$t(7 ; 14)(q 21 ; q 32)$ and variants $(I G H / C D K 6)$. Although these translocations, particularly $\mathrm{t}(2 ; 7)(\mathrm{p} 11 ; \mathrm{q} 21)$, have been reported in several cases of splenic marginal zone lymphoma (SMZL), they were unequivocally identified in 12 CLL patients (100-104). Unfortunately, no data on cell morphology, immunophenotype, or prognosis, are available.

Of note, in SMZL and CLL, $t(2 ; 7)$ is more frequent compared with the two other translocations, $t(7 ; 14)$ and $t(7 ; 22)$. No explanation has been provided as to why $I G K$ is more likely than $I G H$ to juxtapose to $C D K 6$, contrary to the other translocations in which $I G H$ is much more frequently rearranged (104). Of the 11 cases retrieved from the literature, 7 had a $(2 ; 7)(\mathrm{p} 11 ; \mathrm{q} 21)$ translocation (63.6\%), 3 had at $(7 ; 14)(27.3 \%)$ and 1 had a $t(7 ; 22)$ (q21;q11) (9.1\%). Our series included 1 case with $t(2 ; 7)$ and 1 case with $\mathrm{t}(7 ; 22)$. The translocation was the sole abnormality or included in a complex karyotype in 4 cases each.
The $\mathrm{t}(7 ; 14)(\mathrm{q} 21 ; \mathrm{q} 32)$ and its variants lead to overexpression of the CDK6 gene $(103,105,106)$. CDK6 and CDK4 are serine/threonine kinases, members of the cyclin-dependent protein kinase family, involved in the control of the cell cycle and differentiation. CDK6 is important for G1 phase cell cycle progression and $\mathrm{G} 1 / \mathrm{S}$ transition by phosphorylating and inactivating the RB1 protein (107-110).

t(9;14)(p13;q32) [IGH/paired box gene 5 (PAX5)]. Although the $\mathrm{t}(9 ; 14)(\mathrm{p} 13 ; \mathrm{q} 32)$ and its variants have been mostly identified in diffuse large B-cell lymphoma (109), the $t(9 ; 14)$ has also been found in 7 CLL cases (111-114). Few data are available on the cell morphology, but plasmacytoid differentiation is a common characteristic.

Although no trisomy 12 was found, a duplication of part of its long arm was identified in 2 cases. The $t(9 ; 14)$ was included in a complex karyotype in 4 patients, but present as the sole abnormality in the remaining 3 patients.

This translocation leads to the overexpression of the PAX5 gene $(115,116)$. The nuclear transcription factor encoded by this gene is a B-cell lineage-specific activator protein that is expressed during the early, but not the late stages of B-cell differentiation. It restricts the developmental potential of progenitor cells to the B lymphoid pathway by suppressing alternative cell fates and is also involved in the regulation of the CD19 gene, a B lymphoid-specific target gene (117-119).

$t(6 ; 14)(p 21 ; q 32)(I G H / C C N D 3)$. Although the $\mathrm{t}(6 ; 14)(\mathrm{p} 21 ; \mathrm{q} 32)$ has been mostly identified in multiple myeloma (118), it has also been found in diffuse large B-cell lymphoma, splenic lymphoma with villous lymphocytes, SMZL and MCL $(120,121)$. The $t(6 ; 14)$ was identified as the sole chromosomal abnormality in a male patient with CLL associated with atypical cell morphology and involvement of CCND3 (122).

This translocation leads to the overexpression of the $C C N D 3$ gene $(120,123)$. This gene, which is closely related in sequence to the $C C N D 1$ gene, codes a protein belonging to the highly conserved cyclin family. Similar to CCND1, this protein regulates a process that promotes the G1/S cell cycle transition (124-126).

\section{IG translocation-associated CLL is heterogeneous}

The main characteristics of the translocations for which the partner gene was identified are summarized in Table IV. IG translocations result in the deregulated expression of genes involved in several pathways. All the partner genes thus far identified are involved in the control of cell proliferation and/or apoptosis (127). In the majority of the cases, the translocated partner gene becomes transcriptionally deregulated as a consequence of its transposition into the IG locus (128).

Although the number of cases with a given translocation is sometimes low, it appears that CLL associated with IG translocations is characterized by atypical cell morphology, including plasmacytoid characteristics, and the propensity of being enriched in PLs. The IGHV mutational status varies between translocations, those with unmutated $I G H V$ presumably involving cells at an earlier stage of the B-cell lineage.

With the exception of $t(14 ; 18)$, prognosis appears to be poor for the translocations for which sufficient data is 


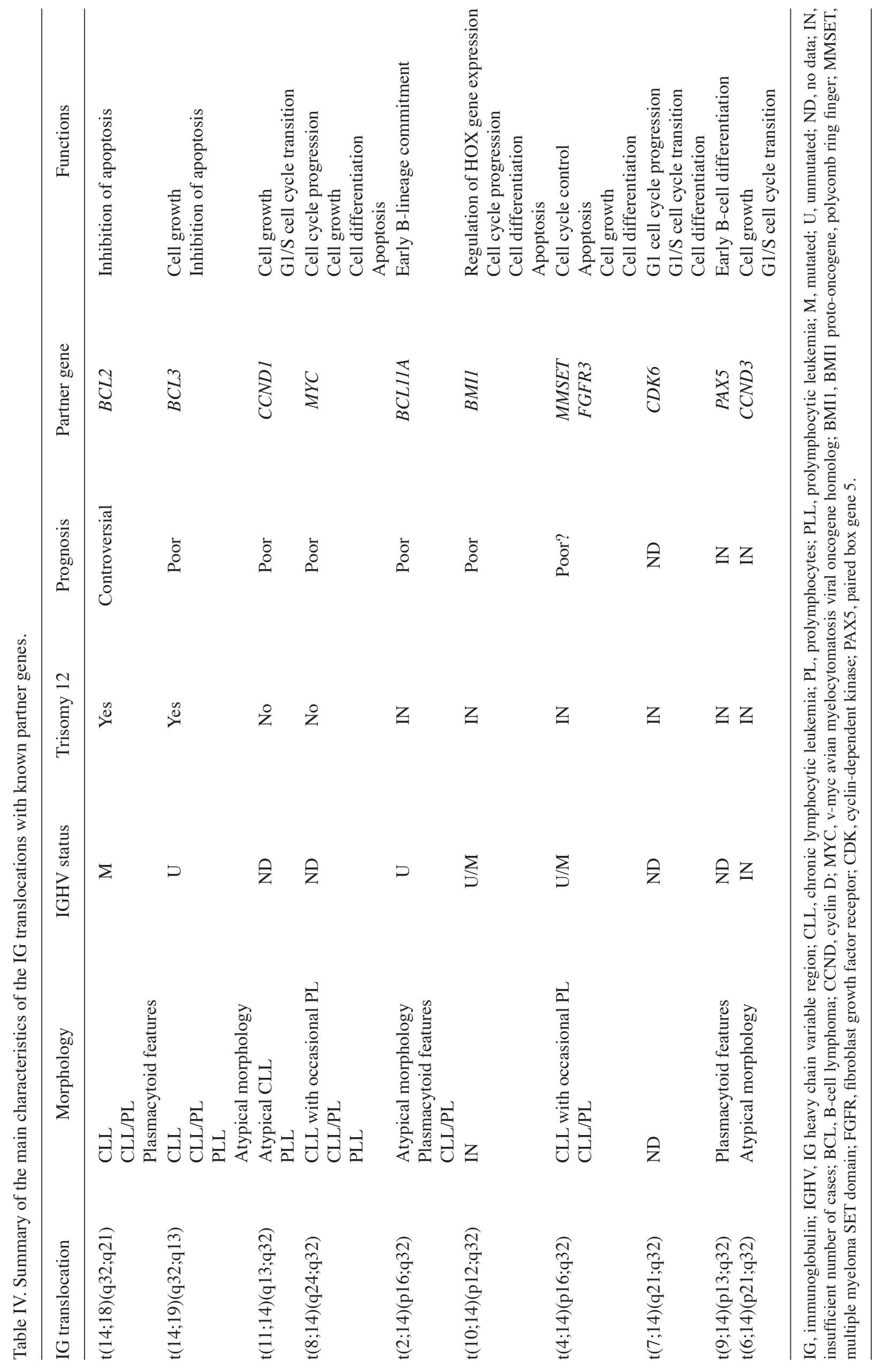


available $(123,129,130)$. Davids et al (131) demonstrated that the time to first treatment was significantly shorter among CLL patients harboring $14 \mathrm{q} 32$ translocations without $\mathrm{t}(14 ; 18)$, compared with those with $\mathrm{t}(14 ; 18)$. Furthermore, the presence of an $I G H$ translocation associated with a del(13q) was shown to confer a poorer prognosis compared with del(13q) alone (132).

Although most centers currently use FISH to identify trisomy 12 and deletions of 13q14, 11q22 and 17p13, which are known to have prognostic significance, it is evident that searching for translocations involving not only $I G H$, but also $I G L$ and $I G K$, by banding and molecular cytogenetics, will add new information. Furthermore, as the prognosis depends on the partner gene involved in the translocation, it is important to identify this partner gene, at least in recurrent translocations, to ensure the patients receive optimal treatment.

\section{Acknowledgements}

We would like to thank all the physicians from the different hospitals who sent us samples for cytogenetic analyses. We are grateful to the technicians of the cytogenetic laboratory for their skilled work.

\section{References}

1. Dores GM, Anderson WF, Curtis RE, Landgren O, Ostroumova E, Bluhm EC, Rabkin CS, Devesa SS and Linet MS: Chronic lymphocytic leukaemia and small lymphocytic lymphoma: Overview of the descriptive epidemiology. Br J Haematol 139: 809-819, 2007

2. Nabhan C and Rosen ST: Chronic lymphocytic leukemia: A clinical review. JAMA 312: 2265-2276, 2014

3. Swerdlow SH, Campo E, Harris NL, Jaffe ES, Pileri SA, Stein H, Thiele J and Vardiman JW (eds): WHO Classification of Tumours of Hematopoietic and Lymphoid Tissues. 4th edition IARC press, Lyon, 2008.

4. Galton DA, Goldman JM, Wiltshaw E, Catovsky D, Henry K and Goldenberg GJ: Prolymphocytic leukaemia. Br J Haematol 27 7-23, 1974

5. Kjeldsberg CR and Marty J: Prolymphocytic transformation of chronic lymphocytic leukemia. Cancer 48: 2447-2457, 1981.

6. DiGiuseppe JA and Borowitz MJ: Clinical utility of flow cytometry in the chronic lymphoid leukemias. Semin Oncol 25: 6-10, 1998.

7. Armitage JO, Dick FR and Corder MP: Diffuse histiocytic lymphoma complicating chronic lymphocytic leukemia. Cancer 41: 422-427, 1978.

8. Parikh SA, Rabe KG, Call TG, Zent CS, Habermann TM, Ding W, Leis JF, Schwager SM, Hanson CA, Macon WR, et al: Diffuse large B-cell lymphoma (Richter syndrome) in patients with chronic lymphocytic leukaemia (CLL): A cohort study of newly diagnosed patients. Br J Haematol 162: 774-782, 2013.

9. Rai KR, Sawitsky A, Cronkite EP, Chanana AD, Levy RN and Pasternack BS: Clinical staging of chronic lymphocytic leukemia. Blood 46: 219-234, 1975.

10. Binet JL, Lepoprier M, Dighiero G, Charron D, D'Athis P, Vaugier G, Beral HM, Natali JC, Raphael M, Nizet B, et al: A clinical staging system for chronic lymphocytic leukemia: Prognostic significance. Cancer 40: 855-864, 1977.

11. Van Bockstaele F, Verhasselt B and Philippé J: Prognostic markers in chronic lymphocytic leukemia: A comprehensive review. Blood Rev 23: 25-47, 2009.

12. Villamor N, Conde L, Martínez-Trillos A, Cazorla M, Navarro A, Beà $\mathrm{S}$, López $\mathrm{C}$, Colomer $\mathrm{D}$, Pinyol $\mathrm{M}$, Aymerich $\mathrm{M}$, et al: NOTCH1 mutations identify a genetic subgroup of chronic lymphocytic leukemia patients with high risk of transformation and poor outcome. Leukemia 27: 1100-1106, 2013.

13. Jeromin S, Weissmann S, Haferlach C, Dicker F, Bayer K, Grossmann V, Alpermann T, Roller A, Kohlmann A, Haferlach T, et al: SF3B1 mutations correlated to cytogenetics and mutations in NOTCH1, FBXW7, MYD88, XPO1 and TP53 in 1160 untreated CLL patients. Leukemia 28: 108-117, 2014
14. Puiggros A, Puigdecanet E, Salido M, Ferrer A, Abella E, Gimeno E, Nonell L, Herranz MJ, Galván AB, Rodríguez-Rivera $\mathrm{M}$, et al: Genomic arrays in chronic lymphocytic leukemia routine clinical practice: Are we ready to substitute conventional cytogenetics and fluorescence in situ hybridization techniques? Leuk Lymphoma 54: 986-995, 2013.

15. Matutes E, Owusu-Ankomah K, Morilla R, Garcia Marco J, Houlihan A, Que TH and Catovsky D: The immunological profile of B-cell disorders and proposal of a scoring system for the diagnosis of CLL. Leukemia 8: 1640-1645, 1994.

16. Cheson BD, Bennett JM, Grever M, Kay N, Keating MJ, O'Brien S and Rai KR: National Cancer Institute-sponsored Working Group guidelines for chronic lymphocytic leukemia: Revised guidelines for diagnosis and treatment. Blood 87: 4990-4997, 1996.

17. Hallek M, Cheson BD, Catovsky D, Caligaris-Cappio F, Dighiero G, Döhner H, Hillmen P, Keating MJ, Montserrat E, Rai KR, et al; International Workshop on Chronic Lymphocytic Leukemia: Guidelines for the diagnosis and treatment of chronic lymphocytic leukemia: A report from the International Workshop on Chronic Lymphocytic Leukemia updating the National Cancer Institute-Working Group 1996 guidelines. Blood 111: 5446-5456, 2008.

18. Shaffer LG, McGowan-Jordan J and Schmid M: An International System for Human Cytogenetic Nomenclature. Karger AG, Basel, 2013.

19. Smoley SA, Van Dyke DL, Kay NE, Heerema NA, Dell' Aquila ML, Dal Cin P, Koduru P, Aviram A, Rassenti L, Byrd JC, et al: Standardization of fluorescence in situ hybridization studies on chronic lymphocytic leukemia (CLL) blood and marrow cells by the CLL Research Consortium. Cancer Genet Cytogenet 203: 141-148, 2010.

20. De Braekeleer M, Le Bris MJ, Basinko A, Morel F and Douet-Guilbert N: Incidence of chromosomal anomalies detected by interphase fluorescent in situ hybridization in chronic lymphoid leukemia. Int J Hematol Oncol 4: 133-141, 2015.

21. De Braekeleer M, De Braekeleer E and Douet-Guilbert N: Geographic/ethnic variability of chromosomal and molecular abnormalities in leukemia. Expert Rev Anticancer Ther 15: 1093-1102, 2015.

22. De Braekeleer E, Douet-Guilbert N, Morel F, Le Bris MJ, Férec C and De Braekeleer M: RUNX1 translocations and fusion genes in malignant hemopathies. Future Oncol 7: 77-91, 2011.

23. De Braekeleer E, Douet-Guilbert N, Morel F, Le Bris MJ, Basinko A and De Braekeleer M: ETV6 fusion genes in hematological malignancies: A review. Leuk Res 36: 945-961, 2012.

24. Schmidt HH,Dyomin VG, Palanisamy N, Itoyama T, Nanjangud G, Pirc-Danoewinata H, Haas OA and Chaganti RS: Deregulation of the carbohydrate (chondroitin 4) sulfotransferase 11 (CHST11) gene in a B-cell chronic lymphocytic leukemia with a $\mathrm{t}(12 ; 14)$ (q23;q32). Oncogene 23: 6991-6996, 2004.

25. Aamot HV, Bjørnslett M, Delabie J and Heim S: t(14;22)(q32;q11) in non-Hodgkin lymphoma and myeloid leukaemia: Molecular cytogenetic investigations. Br J Haematol 130: 845-851, 2005.

26. Kominami R: Role of the transcription factor Bcl11b in development and lymphomagenesis. Proc Jpn Acad Ser B Phys Biol Sci 88: 72-87, 2012.

27. Obata M, Kominami R and Mishima Y: BCL11B tumor suppressor inhibits HDM2 expression in a p53-dependent manner. Cell Signal 24: 1047-1052, 2012.

28. Dyer MJ, Zani VJ, Lu WZ, O'Byrne A, Mould S, Chapman R, Heward JM, Kayano H, Jadayel D, Matutes E, et al: BCL2 translocations in leukemias of mature B cells. Blood 83: 3682-3688, 1994.

29. Lin P, Jetly R, Lennon PA, Abruzzo LV, Prajapati S and Medeiros LJ: Translocation $(18 ; 22)(\mathrm{q} 21 ; \mathrm{q} 11)$ in B-cell lymphomas: A report of 4 cases and review of the literature. Hum Pathol 39: 1664-1672, 2008.

30. Baseggio L, Geay MO, Gazzo S, Berger F, Traverse-Glehen A, Ffrench M, Hayette S, Callet-Bauchu E, Verney A, Morel D, et al: In non-follicular lymphoproliferative disorders, IGH/BCL2-fusion is not restricted to chronic lymphocytic leukaemia. Br J Haematol 158: 489-498, 2012.

31. Tang G, Banks HE, Sargent RL, Medeiros LJ and Abruzzo LV: Chronic lymphocytic leukemia with $\mathrm{t}(14 ; 18)(\mathrm{q} 32 ; \mathrm{q} 21)$. Hum Pathol 44: 598-605, 2013.

32. Put N, Meeus P, Chatelain B, Rack K, Boeckx N, Nollet F, Graux C, Van Den Neste E, Janssens A, Madoe V, et al: Translocation $\mathrm{t}(14 ; 18)$ is not associated with inferior outcome in chronic lymphocytic leukemia. Leukemia 23: 1201-1204, 2009. 
33. Sen F, Lai R and Albitar M: Chronic lymphocytic leukemia with $\mathrm{t}(14 ; 18)$ and trisomy 12. Arch Pathol Lab Med 126: 1543-1546, 2002.

34. Matutes E, Oscier D, Garcia-Marco J, Ellis J, Copplestone A, Gillingham R, Hamblin T, Lens D, Swansbury GJ and Catovsky D: Trisomy 12 defines a group of CLL with atypical morphology: Correlation between cytogenetic, clinical and laboratory features in 544 patients. Br J Haematol 92: 382-388, 1996.

35. Cleary ML, Smith SD and Sklar J: Cloning and structural analysis of cDNAs for bcl-2 and a hybrid bcl-2/immunoglobulin transcript resulting from the $\mathrm{t}(14 ; 18)$ translocation. Cell 47: 19-28, 1986.

36. Hua C, Zorn S, Jensen JP, Coupland RW, Ko HS, Wright JJ and Bakhshi A: Consequences of the $t(14 ; 18)$ chromosomal translocation in follicular lymphoma: Deregulated expression of a chimeric and mutated BCL-2 gene. Oncogene Res 2: 263-275, 1988.

37. Tsujimoto Y and Croce CM: Analysis of the structure, transcripts, and protein products of bcl-2, the gene involved in human follicular lymphoma. Proc Natl Acad Sci USA 83: 5214-5218, 1986.

38. Oltvai ZN, Milliman CL and Korsmeyer SJ: Bcl-2 heterodimerizes in vivo with a conserved homolog, Bax, that accelerates programmed cell death. Cell 74: 609-619, 1993.

39. Martín-Subero JI, Ibbotson R, Klapper W, Michaux L, Callet-Bauchu E, Berger F, Calasanz MJ, De Wolf-Peeters C, Dyer MJ, Felman P, et al: A comprehensive genetic and histopathologic analysis identifies two subgroups of B-cell malignancies carrying a $\mathrm{t}(14 ; 19)(\mathrm{q} 32 ; \mathrm{q} 13)$ or variant BCL3-translocation. Leukemia 21: 1532-1544, 2007.

40. Huh YO, Abruzzo LV, Rassidakis GZ, Parry-Jones N, Schlette E, Brito-Bapabulle V, Matutes E, Wotherspoon A, Keating MJ Medeiros LJ, et al: The $\mathrm{t}(14 ; 19)(\mathrm{q} 32 ; \mathrm{q} 13)$-positive small B-cell leukaemia: A clinicopathologic and cytogenetic study of seven cases. Br J Haematol 136: 220-228, 2007.

41. Huh YO, Schweighofer CD, Ketterling RP, Knudson RA, Vega F, Kim JE, Luthra R, Keating MJ, Medeiros LJ and Abruzzo LV: Chronic lymphocytic leukemia with $\mathrm{t}(14 ; 19)(\mathrm{q} 32 ; \mathrm{q} 13)$ is characterized by atypical morphologic and immunophenotypic features and distinctive genetic features. Am J Clin Pathol 135: 686-696, 2011.

42. Michaux L, Mecucci C, Stul M, Wlodarska I, Hernandez JM, Meeus P, Michaux JL, Scheiff JM, Noël H, Louwagie A, et al: BCL3 rearrangement and $t(14 ; 19)(q 32 ; q 13)$ in lymphoproliferative disorders. Genes Chromosomes Cancer 15: 38-47, 1996.

43. Michaux L, Dierlamm J, Wlodarska I, Bours V, Van den Berghe $H$ and Hagemeijer A: $t(14 ; 19) / B C L 3$ rearrangements in lymphoproliferative disorders: A review of 23 cases. Cancer Genet Cytogenet 94: 36-43, 1997.

44. McKeithan TW, Takimoto GS, Ohno H, Bjorling VS, Morgan R, Hecht BK, Dubé I, Sandberg AA and Rowley JD: BCL3 rearrangements and $t(14 ; 19)$ in chronic lymphocytic leukemia and other B-cell malignancies: A molecular and cytogenetic study. Genes Chromosomes Cancer 20: 64-72, 1997.

45. Chapiro E, Radford-Weiss I, Bastard C, Luquet I, Lefebvre C, Callet-Bauchu E, Leroux D, Talmant P, Mozziconacci MJ, Mugneret F, et al: The most frequent $\mathrm{t}(14 ; 19)(\mathrm{q} 32 ; \mathrm{q} 13)$-positive $\mathrm{B}$-cell malignancy corresponds to an aggressive subgroup of atypical chronic lymphocytic leukemia. Leukemia 22: 2123-2127, 2008.

46. Schweighofer CD, Huh YO, Luthra R, Sargent RL, Ketterling RP, Knudson RA, Barron LL, Medeiros LJ, Keating MJ and Abruzzo LV: The B cell antigen receptor in atypical chronic lymphocytic leukemia with $\mathrm{t}(14 ; 19)(\mathrm{q} 32 ; \mathrm{q} 13)$ demonstrates remarkable stereotypy. Int J Cancer 128: 2759-2764, 2011.

47. Shin SY, Park CJ, Lee KH, Huh J, Chi HS and Seo EJ: An illustrative case of $t(14 ; 19) / B C L 3$ rearrangement as a karyotypic evolution of chronic lymphocytic leukemia. Ann Hematol 92: 1717-1719, 2013

48. Murray F, Darzentas N, Hadzidimitriou A, Tobin G, Boudjogra M, Scielzo C, Laoutaris N, Karlsson K, Baran-Marzsak F, Tsaftaris A, et al: Stereotyped patterns of somatic hypermutation in subsets of patients with chronic lymphocytic leukemia: Implications for the role of antigen selection in leukemogenesis. Blood 111: 1524-1533, 2008

49. McKeithan TW, Ohno H and Diaz MO: Identification of a transcriptional unit adjacent to the breakpoint in the 14;19 translocation of chronic lymphocytic leukemia. Genes Chromosomes Cancer 1: 247-255, 1990.

50. Ohno H, Takimoto $\mathrm{G}$ and McKeithan TW: The candidate proto-oncogene bcl-3 is related to genes implicated in cell lineage determination and cell cycle control. Cell 60: 991-997, 1990.
51. Bours V, Franzoso G, Azarenko V, Park S, Kanno T, Brown K and Siebenlist U: The oncoprotein Bcl-3 directly transactivates through kappa B motifs via association with DNA-binding p50B homodimers. Cell 72: 729-739, 1993.

52. Dechend R, Hirano F, Lehmann K, Heissmeyer V, Ansieau S, Wulczyn FG, Scheidereit C and Leutz A: The Bcl-3 oncoprotein acts as a bridging factor between NF-kappaB/Rel and nuclear co-regulators. Oncogene 18: 3316-3323, 1999.

53. Orlowski RZ and Baldwin AS Jr: NF-kappaB as a therapeutic target in cancer. Trends Mol Med 8: 385-389, 2002.

54. Baldwin AS: Control of oncogenesis and cancer therapy resistance by the transcription factor NF-kappaB. J Clin Invest 107: 241-246, 2001.

55. Kashatus D, Cogswell P and Baldwin AS: Expression of the Bcl-3 proto-oncogene suppresses p53 activation. Genes Dev 20: 225-235, 2006

56. Huret JL: $\mathrm{t}(11 ; 14)(\mathrm{q} 13 ; \mathrm{q} 32)$. Atlas Genet Cytogenet Oncol Haematol 2: 129-131, 1998

57. Cuneo A, de Angeli C, Roberti MG, Piva N, Bigoni R, Gandini D, Rigolin GM, Moretti S, Cavazzini P, del Senno L, et al: Richter's syndrome in a case of atypical chronic lymphocytic leukaemia with the $\mathrm{t}(11 ; 14)(\mathrm{q} 13 ; \mathrm{q} 32)$ : Role for a $\mathrm{p} 53$ exon 7 gene mutation. Br J Haematol 92: 375-381, 1996.

58. Späth-Schwalbe E, Flath B, Kaufmann O, Thiel G, Brinckmann R, Dietel M and Possinger K: An unusual case of leukemic non-Hodgkin's lymphoma with blastic transformation. Ann Hematol 79: 217-221, 2000.

59. Cuneo A, Balboni M, Piva N, Rigolin GM, Roberti MG, Mejak C, Moretti S, Bigoni R, Balsamo R, Cavazzini P, et al: Atypical chronic lymphocytic leukaemia with $\mathrm{t}(11 ; 14)(\mathrm{q} 13 ; \mathrm{q} 32)$ : Karyotype evolution and prolymphocytic transformation. Br J Haematol 90: 409-416, 1995.

60. De Angeli C, Gandini D, Cuneo A, Moretti S, Bigoni R, Roberti MG, Bardi A, Castoldi GL and del Senno L: BCL-1 rearrangements and p53 mutations in atypical chronic lymphocytic leukemia with $\mathrm{t}(11 ; 14)(\mathrm{q} 13 ; \mathrm{q} 32)$. Haematologica 85: 913-921, 2000.

61. Cuneo A, Bigoni R, Negrini M, Bullrich F, Veronese ML, Roberti MG, Bardi A, Rigolin GM, Cavazzini P, Croce CM, et al: Cytogenetic and interphase cytogenetic characterization of atypical chronic lymphocytic leukemia carrying BCL1 translocation. Cancer Res 57: 1144-1150, 1997.

62. Komatsu H, Yoshida K, Seto M, Iida S, Aikawa T, Ueda R and Mikuni C: Overexpression of PRAD1 in a mantle zone lymphoma patient with a $\mathrm{t}(11 ; 22)(\mathrm{q} 13 ; \mathrm{q11})$ translocation. Br J Haematol 85: 427-429, 1993.

63. Nishida Y, Takeuchi K, Tsuda K, Ugai T, Sugihara H, Yamakura M, Takeuchi M and Matsue K: Acquisition of $\mathrm{t}(11 ; 14)$ in a patient with chronic lymphocytic leukemia carrying both $\mathrm{t}(14 ; 19)(\mathrm{q} 32 ; \mathrm{q} 13.1)$ and +12. Eur J Haematol 91: 179-182, 2013.

64. Matutes E, Carrara P, Coignet L, Brito-Babapulle V, Villamor N, Wotherspoon A and Catovsky D: FISH analysis for BCL-1 rearrangements and trisomy 12 helps the diagnosis of atypical B cell leukaemias. Leukemia 13: 1721-1726, 1999.

65. Rimokh R, Berger F, Bastard C, Klein B, French M, Archimbaud E, Rouault JP, Santa Lucia B, Duret L, Vuillaume M, et al: Rearrangement of CCND1 (BCL1/PRAD1) 3' untranslated region in mantle-cell lymphomas and t(11q13)-associated leukemias. Blood 83: 3689-3696, 1994

66. Sherr CJ: The Pezcoller lecture: Cancer cell cycles revisited. Cancer Res 60: 3689-3695, 2000.

67. Bates S, Bonetta L, MacAllan D, Parry D, Holder A, Dickson C and Peters G: CDK6 (PLSTIRE) and CDK4 (PSK-J3) are a distinct subset of the cyclin-dependent kinases that associate with cyclin D1. Oncogene 9: 71-79, 1994.

68. Reddy K, Satyadev R, Bouman D, Hibbard MK, Lu G and Paolo R: Burkitt $\mathrm{t}(8 ; 14)(\mathrm{q} 24 ; \mathrm{q} 32)$ and cryptic deletion in a CLL patient: Report of a case and review of literature. Cancer Genet Cytogenet 166: 12-21, 2006.

69. Huh YO, Lin KI, Vega F, Schlette E, Yin CC, Keating MJ, Luthra R, Medeiros LJ and Abruzzo LV: MYC translocation in chronic lymphocytic leukaemia is associated with increased prolymphocytes and a poor prognosis. Br J Haematol 142: 36-44, 2008

70. Put N, Van Roosbroeck K, Konings P, Meeus P, Brusselmans C, Rack K, Gervais C, Nguyen-Khac F, Chapiro E, Radford-Weiss I, et al; BCGHo and the GFCH: Chronic lymphocytic leukemia and prolymphocytic leukemia with MYC translocations: A subgroup with an aggressive disease course. Ann Hematol 91: 863-873, 2012. 
71. Asirvatham JR, Brody J, Vora R, Kolitz JE, Fields SZ, Sreekantaiah C and Zhang X: Prognostic significance of isolated $\mathrm{t}(8: 14)$ in chronic lymphocytic leukemia. Leuk Lymphoma 55: 685-688, 2014.

72. Taub R, Kirsch I, Morton C, Lenoir G, Swan D, Tronick S, Aaronson S and Leder P: Translocation of the c-myc gene into the immunoglobulin heavy chain locus in human Burkit lymphoma and murine plasmacytoma cells. Proc Natl Acad Sci USA 79: 7837-7841, 1982

73. Kelly K and Siebenlist U: The role of c-myc in the proliferation of normal and neoplastic cells. J Clin Immunol 5: 65-77, 1985.

74.Li Z, Van Calcar S, Qu C, Cavenee WK, Zhang MQ and Ren B: A global transcriptional regulatory role for c-Myc in Burkitt's lymphoma cells. Proc Natl Acad Sci USA 100: 8164-8169, 2003.

75.Dang CV, Resar LM, Emison E, Kim S, Li Q, Prescott JE, Wonsey D and Zeller K: Function of the c-Myc oncogenic transcription factor. Exp Cell Res 253: 63-77, 1999.

76. Hoffman B and Liebermann DA: Apoptotic signaling by c-MYC. Oncogene 27: 6462-6472, 2008

77. Satterwhite E, Sonoki T, Willis TG, Harder L, Nowak R, Arriola EL, Liu H, Price HP, Gesk S, Steinemann D, et al The BCL11 gene family: Involvement of BCL11A in lymphoid malignancies. Blood 98: 3413-3420, 2001.

78. Yin CC, Lin KI, Ketterling RP, Knudson RA, Medeiros LJ, Barron LL, Huh YO, Luthra R, Keating MJ and Abruzzo LV: Chronic lymphocytic leukemia with $\mathrm{t}(2 ; 14)(\mathrm{p} 16 ; \mathrm{q} 32)$ involves the BCL11A and IgH genes and is associated with atypical morphologic features and unmutated IgVH genes. Am J Clin Pathol 131: 663-670, 2009.

79. Küppers R, Sonoki T, Satterwhite E, Gesk S, Harder L, Oscier DG, Tucker PW, Dyer MJS and Siebert R: Lack of somatic hypermutation of IG $\mathrm{V}(\mathrm{H})$ genes in lymphoid malignancies with $\mathrm{t}(2 ; 14)(\mathrm{p} 13 ; \mathrm{q} 32)$ translocation involving the BCL11A gene. Leukemia 16: 937-939, 2002.

80.Liu P, Keller JR, Ortiz M, Tessarollo L, Rachel RA, Nakamura T, Jenkins NA and Copeland NG: Bcll1a is essential for normal lymphoid development. Nat Immunol 4 525-532, 2003

81.Pulford K, Banham AH, Lyne L, Jones M, Ippolito GC, Liu H, Tucker PW, Roncador G, Lucas E, Ashe S, et al: The BCL11AXL transcription factor: Its distribution in normal and malignan tissues and use as a marker for plasmacytoid dendritic cells Leukemia 20: 1439-1441, 2006.

82. Rouhigharabaei L, Ferreiro JF, Put N, Michaux L, Tousseyn T, Lefebvre C, Gardiner A, De Kelver W, Demuynck H, Verschuere $\mathrm{J}$, et al: BMI1, the polycomb-group gene, is recurrently targeted by genomic rearrangements in progressive B-cell leukemia/lymphoma. Genes Chromosomes Cancer 52: 928-944 2013 .

83.Li Z, Cao R, Wang M, Myers MP, Zhang Y and Xu RM: Structure of a Bmi-1-Ring1B polycomb group ubiquitin ligase complex. J Biol Chem 281: 20643-20649, 2006.

84. Raaphorst FM, Otte AP and Meijer CJ: Polycomb-group genes as regulators of mammalian lymphopoiesis. Trends Immunol 22: 682-690, 2001.

85. Ringrose L and Paro R: Polycomb/Trithorax response elements and epigenetic memory of cell identity. Development 134 223-232, 2007.

86. Sauvageau M and Sauvageau G: Polycomb group proteins: Multi-faceted regulators of somatic stem cells and cancer. Cell Stem Cell 7: 299-313, 2010.

87. Siddique HR and Saleem M: Role of BMI1, a stem cell factor, in cancer recurrence and chemoresistance: Preclinical and clinical evidences. Stem Cells 30: 372-378, 2012.

88. Silva J, García JM, Peña C, García V, Domínguez G, Suárez D, Camacho FI, Espinosa R, Provencio M, España P, et al: Implication of polycomb members Bmi-1, Mel-18, and Hpc-2 in the regulation of p16INK4a, p14ARF, h-TERT, and c-Myc expression in primary breast carcinomas. Clin Cancer Res 12 6929-6936, 2006

89. Jacobs JJ, Scheijen B, Voncken JW, Kieboom K, Berns A and van Lohuizen M: Bmi-1 collaborates with c-Myc in tumorigenesis by inhibiting c-Myc-induced apoptosis via INK4a/ARF Genes Dev 13: 2678-2690, 1999.

90. Bacher U, Haferlach T, Schnittger S, Weiss T, Burkhard O, Bechtel B, Kern W and Haferlach C: Detection of a $\mathrm{t}(4 ; 14)$ (p16;q32) in two cases of lymphoma showing both the immunophenotype of chronic lymphocytic leukemia. Cancer Genet Cytogenet 200: 170-174, 2010.
91. Cerny J, Yu H and Miron PM: Novel FGFR3 rearrangement $\mathrm{t}(4 ; 22)(\mathrm{p} 16 ; \mathrm{q} 11.2)$ in a patient with chronic lymphocytic leukemia/small lymphocytic lymphoma. Ann Hematol 92: 1433-1435, 2013.

92. Geller MD, Pei Y, Spurgeon SE, Durum C and Leeborg NJ: Chronic lymphocytic leukemia with a FGFR3 translocation: case report and literature review of an uncommon cytogenetic event. Cancer Genet 207: 340-343, 2014.

93. Kalff A and Spencer A: The t(4;14) translocation and FGFR3 overexpression in multiple myeloma: Prognostic implications and current clinical strategies. Blood Cancer J 2: e89, 2012.

94. Chesi M, Nardini E, Lim RSC, Smith KD, Kuehl WM and Bergsagel PL: The $\mathrm{t}(4 ; 14)$ translocation in myeloma dysregulates both FGFR3 and a novel gene, MMSET, resulting in IgH/MMSET hybrid transcripts. Blood 92: 3025-3034, 1998

95. Chesi M, Nardini E, Brents LA, Schröck E, Ried T, Kuehl WM and Bergsagel PL: Frequent translocation $\mathrm{t}(4 ; 14)(\mathrm{p} 16.3 ; \mathrm{q} 32.3)$ in multiple myeloma is associated with increased expression and activating mutations of fibroblast growth factor receptor 3 . Nat Genet 16: 260-264, 1997

96. Lauring J, Abukhdeir AM,Konishi H, Garay JP, Gustin JP, Wang Q, Arceci RJ, Matsui W and Park BH: The multiple myeloma associated MMSET gene contributes to cellular adhesion, clonogenic growth, and tumorigenicity. Blood 111: 856-864, 2008.

97. Martinez-Garcia E, Popovic R, Min DJ, Sweet SM, Thomas PM, Zamdborg L, Heffner A, Will C, Lamy L, Staudt LM, et al: The MMSET histone methyl transferase switches global histone methylation and alters gene expression in $\mathrm{t}(4 ; 14)$ multiple myeloma cells. Blood 117: 211-220, 2011.

98. Hart KC, Robertson SC and Donoghue DJ: Identification of tyrosine residues in constitutively activated fibroblast growth factor receptor 3 involved in mitogenesis, Stat activation, and phosphatidylinositol 3-kinase activation. Mol Biol Cell 12: 931-942, 2001

99. L'Hôte CG and Knowles MA: Cell responses to FGFR3 signalling: Growth, differentiation and apoptosis. Exp Cell Res 304: 417-431, 2005

100. Vahdati M, Graafland H and Emberger JM: Karyotype analysis of B-lymphocytes transformed by Epstein-Barr virus in 21 patients with B cell chronic lymphocytic leukemia. Hum Genet 63: 327-331, 1983

101. Oscier DG, Gardiner A and Mould S: Structural abnormalities of chromosome $7 \mathrm{q}$ in chronic lymphoproliferative disorders. Cancer Genet Cytogenet 92: 24-27, 1996.

102. Fink SR, Smoley SA, Stockero KJ, Paternoster SF, Thorland EC, Van Dyke DL, Shanafelt TD, Zent CS, Call TG, Kay NE, et al: Loss of TP53 is due to rearrangements involving chromosome region $17 \mathrm{p} 10$ approximately p12 in chronic lymphocytic leukemia. Cancer Genet Cytogenet 167: 177-181, 2006.

103. Hayette S, Tigaud I, Callet-Bauchu E, Ffrench M, Gazzo S, Wahbi $\mathrm{K}$, Callanan M, Felman P, Dumontet C, Magaud JP, et al: In B-cell chronic lymphocytic leukemias, 7q21 translocations lead to overexpression of the CDK6 gene. Blood 102: 1549-1550, 2003.

104. Douet-Guilbert N, Tous C, Le Flahec G, Bovo C, Le Bris MJ, Basinko A, Morel F and De Braekeleer M: Translocation $\mathrm{t}(2 ; 7)$ (p11;q21) associated with the CDK6/IGK rearrangement is a rare but recurrent abnormality in B-cell lymphoproliferative malignancies. Cancer Genet 207: 83-86, 2014.

105. Corcoran MM, Mould SJ, Orchard JA, Ibbotson RE, Chapman RM, Boright AP, Platt C, Tsui LC, Scherer SW and Oscier DG: Dysregulation of cyclin dependent kinase 6 expression in splenic marginal zone lymphoma through chromosome 7q translocations. Oncogene 18: 6271-6277, 1999.

106. Brito-Babapulle V, Gruszka-Westwood AM, Platt G, Andersen CL, Elnenaei MO, Matutes E, Wotherspoon AC, Weston-Smith SG and Catovsky D: Translocation $\mathrm{t}(2 ; 7)$ (p12;q21-22) with dysregulation of the CDK6 gene mapping to 7q21-22 in a non-Hodgkin's lymphoma with leukemia. Haematologica 87: 357-362, 2002.

107. Ruas M, Gregory F, Jones R, Poolman R, Starborg M, Rowe J, Brookes S and Peters G: CDK4 and CDK6 delay senescence by kinase-dependent and p16INK4a-independent mechanisms. Mol Cell Biol 27: 4273-4282, 2007.

108. Handschick K, Beuerlein K, Jurida L, Bartkuhn M, Müller H, Soelch J, Weber A, Dittrich-Breiholz O, Schneider H, Scharfe M, et al: Cyclin-dependent kinase 6 is a chromatin-bound cofactor for NF-kB-dependent gene expression. Mol Cell 53: 193-208, 2014

109. Grossel MJ and Hinds PW: From cell cycle to differentiation: An expanding role for cdk6. Cell Cycle 5: 266-270, 2006. 
110. Matushansky I, Radparvar F and Skoultchi AI: CDK6 blocks differentiation: Coupling cell proliferation to the block to differentiation in leukemic cells. Oncogene 22: 4143-4149, 2003.

111. Offit K, Parsa NZ, Filippa D, Jhanwar SC and Chaganti RS $\mathrm{t}(9 ; 14)(\mathrm{p} 13 ; \mathrm{q} 32)$ denotes a subset of low-grade non-Hodgkin's lymphoma with plasmacytoid differentiation. Blood 80: 2594-2599, 1992.

112. Finn WG, Kay NE, Kroft SH, Church S and Peterson LC: Secondary abnormalities of chromosome $6 \mathrm{q}$ in B-cell chronic lymphocytic leukemia: A sequential study of karyotypic instability in 51 patients. Am J Hematol 59: 223-229, 1998.

113. Dicker F, Schnittger S, Haferlach T, Kern W and Schoch C: Immunostimulatory oligonucleotide-induced metaphase cytogenetics detect chromosomal aberrations in $80 \%$ of CLL patients: A study of 132 CLL cases with correlation to FISH, IgVH status, and CD38 expression. Blood 108: 3152-3160, 2006.

114. Dascalescu CM, Péoc'h M, Callanan M, Jacob MC, Sotto MF, Gressin R, Sotto JJ and Leroux D: Deletion 7q in B-cell low-grade lymphoid malignancies: A cytogenetic/fluorescence in situ hybridization and immunopathologic study. Cancer Genet Cytogenet 109: 21-28, 1999.

115. Busslinger M, Klix N, Pfeffer P, Graninger PG and Kozmik Z: Deregulation of PAX-5 by translocation of the Emu enhancer of the IgH locus adjacent to two alternative PAX-5 promoters in a diffuse large-cell lymphoma. Proc Natl Acad Sci USA 93: 6129-6134, 1996

116. Iida S, Rao PH, Nallasivam P, Hibshoosh H, Butler M, Louie DC, Dyomin V, Ohno H, Chaganti RSK and Dalla-Favera R: The $\mathrm{t}(9 ; 14)(\mathrm{p} 13 ; \mathrm{q} 32)$ chromosomal translocation associated with lymphoplasmacytoid lymphoma involves the PAX-5 gene. Blood 88: 4110-4117, 1996.

117. Ohno H, Ueda $\mathrm{C}$ and Akasaka T: The t $(9 ; 14)(\mathrm{p} 13 ; \mathrm{q} 32)$ translocation in B-cell non-Hodgkin's lymphoma. Leuk Lymphoma 36: 435-445, 2000.

118. Barberis A, Widenhorn K, Vitelli L and Busslinger M: A novel B-cell lineage-specific transcription factor present at early but not late stages of differentiation. Genes Dev 4: 849-859, 1990.

119. Eberhard D, Jiménez G, Heavey B and Busslinger M: Transcriptional repression by Pax5 (BSAP) through interaction with corepressors of the Groucho family. EMBO J 19: 2292-2303, 2000

120. Sonoki T, Harder L, Horsman DE, Karran L, Taniguchi I, Willis TG, Gesk S, Steinemann D, Zucca E, Schlegelberger B, et al: Cyclin D3 is a target gene of $\mathrm{t}(6 ; 14)$ (p21.1;q32.3) of mature B-cell malignancies. Blood 98: 2837-2844, 2001.

121. Wlodarska I, Dierickx D, Vanhentenrijk V, Van Roosbroeck K, Pospísilová H, Minnei F, Verhoef G, Thomas J, Vandenberghe P and De Wolf-Peeters C: Translocations targeting CCND2, CCND3, and MYCN do occur in t(11;14)-negative mantle cell lymphomas. Blood 111: 5683-5690, 2008.

122. Cavazzini F, Hernandez JA, Gozzetti A, Russo Rossi A, De Angeli C, Tiseo R, Bardi A, Tammiso E, Crupi R, Lenoci MP, et al: Chromosome 14q32 translocations involving the immunoglobulin heavy chain locus in chronic lymphocytic leukaemia identify a disease subset with poor prognosis. Br J Haematol 142: 529-537, 2008.

123. Shaughnessy J Jr, Gabrea A, Qi Y, Brents L, Zhan F, Tian E, Sawyer J, Barlogie B, Bergsagel PL and Kuehl M: Cyclin D3 at 6 p21 is dysregulated by recurrent chromosomal translocations to immunoglobulin loci in multiple myeloma. Blood 98: 217-223, 2001.

124. Motokura T, Keyomarsi K, Kronenberg HM and Arnold A: Cloning and characterization of human cyclin D3, a cDNA closely related in sequence to the PRAD1/cyclin D1 proto-oncogene. J Biol Chem 267: 20412-20415, 1992.

125. Gumina MR, Xu C and Chiles TC: Cyclin D3 is dispensable for human diffuse large B-cell lymphoma survival and growth: Evidence for redundancy with cyclin E. Cell Cycle 9: 820-828, 2010.

126. Decker T, Schneller F, Hipp S, Miething C, Jahn T, Duyster J and Peschel C: Cell cycle progression of chronic lymphocytic leukemia cells is controlled by cyclin D2, cyclin D3, cyclin-dependent kinase (cdk) 4 and the cdk inhibitor p27. Leukemia 16: 327-334, 2002.

127. Willis TG and Dyer MJS: The role of immunoglobulin translocations in the pathogenesis of B-cell malignancies. Blood 96: $808-822,2000$
128. Küppers R and Dalla-Favera R: Mechanisms of chromosomal translocations in B cell lymphomas. Oncogene 20: 5580-5594, 2001.

129. Nowakowski GS, Dewald GW, Hoyer JD, Paternoster SF, Stockero KJ, Fink SR, Smoley SA, Remstein ED, Phyliky RL, Call TG, et al: Interphase fluorescence in situ hybridization with an IGH probe is important in the evaluation of patients with a clinical diagnosis of chronic lymphocytic leukaemia. Br J Haematol 130: 36-42, 2005.

130. Cavazzini F, Rizzotto L, Sofritti O, Daghia G, Cibien F, Martinelli S, Ciccone M, Saccenti E, Dabusti M, Elkareem AA, et al: Clonal evolution including 14q32/IGH translocations in chronic lymphocytic leukemia: Analysis of clinicobiologic correlations in 105 patients. Leuk Lymphoma 53: 83-88, 2012

131.Davids MS, Vartanov A, Werner L, Neuberg D, Dal Cin P and Brown JR: Controversial fluorescence in situ hybridization cytogenetic abnormalities in chronic lymphocytic leukaemia: New insights from a large cohort. Br J Haematol 170: 694-703, 2015.

132. Gerrie AS, Bruyere H, Chan MJ, Dalal CB, Ramadan KM, Huang SJ, Toze CL and Gillan TL: Immunoglobulin heavy chain(IGH@) translocations negatively impact treatment-free survival for chronic lymphocytic leukemia patients who have an isolated deletion 13q abnormality. Cancer Genet 205: 523-527, 2012.

133. Gerrie AS, Huang SJ, Bruyere H, Dalal C, Hrynchak M, Karsan A, Ramadan KM, Smith AC, Tyson C, Toze CL, et al: Population-based characterization of the genetic landscape of chronic lymphocytic leukemia patients referred for cytogenetic testing in British Columbia, Canada: The role of provincial laboratory standardization. Cancer Genet 207: 316-325, 2014.

134.Lu G, Kong Y and Yue C: Genetic and immunophenotypic profile of IGH@ rearrangement detected by fluorescence in situ hybridization in 149 cases of B-cell chronic lymphocytic leukemia. Cancer Genet Cytogenet 196: 56-63, 2010.

135. Shanafelt TD, Witzig TE, Fink SR, Jenkins RB, Paternoster SF, Smoley SA, Stockero KJ, Nast DM, Flynn HC, Tschumper RC, et al: Prospective evaluation of clonal evolution during long-term follow-up of patients with untreated early-stage chronic lymphocytic leukemia. J Clin Oncol 24: 4634-4641, 2006.

136. Aoun P, Blair HE, Smith LM, Dave BJ, Lynch J, Weisenburger DD, Pavletic SZ and Sanger WG: Fluorescence in situ hybridization detection of cytogenetic abnormalities in B-cell chronic lymphocytic leukemia/small lymphocytic lymphoma. Leuk Lymphoma 45: 1595-1603, 2004.

137. Nelson BP, Gupta R, Dewald GW, Paternoster SF, Rosen ST and Peterson LC: Chronic lymphocytic leukemia FISH panel: Impact on diagnosis. Am J Clin Pathol 128: 323-332, 2007.

138. Flanagan MB, Sathanoori M, Surti U, Soma L and Swerdlow SH: Cytogenetic abnormalities detected by fluorescence in situ hybridization on paraffin-embedded chronic lymphocytic leukemia/small lymphocytic lymphoma lymphoid tissue biopsy specimens. Am J Clin Pathol 130: 620-627, 2008.

139. Jenderny J, Goldmann C, Thede R, Ebrecht M and Korioth F: Detection of clonal aberrations by cytogenetic analysis after different culture methods and by FISH in 129 patients with chronic lymphocytic leukemia. Cytogenet Genome Res 144: $163-168,2014$.

140. Haferlach C, Dicker F, Schnittger S, Kern W and Haferlach T: Comprehensive genetic characterization of CLL: A study on 506 cases analysed with chromosome banding analysis, interphase FISH, $\operatorname{IgV}(\mathrm{H})$ status and immunophenotyping. Leukemia 21: 2442-2451, 2007.

141. Alhourani E, Rincic M, Othman MA, Pohle B, Schlie C, Glaser A and Liehr T: Comprehensive chronic lymphocytic leukemia diagnostics by combined multiplex ligation dependent probe amplification (MLPA) and interphase fluorescence in situ hybridization (iFISH). Mol Cytogenet 7: 79, 2014

142. Döhner H, Stilgenbauer S, Benner A, Leupolt E, Kröber A, Bullinger L, Döhner K, Bentz M and Lichter P: Genomic aberrations and survival in chronic lymphocytic leukemia. N Engl J Med 343: 1910-1916, 2000.

143. Berkova A, Pavlistova L, Babicka L, Houskova L, Tajtlova J, Balazi P, Cmunt E, Schwarz J, Karban J, Trneny M, et al: Combined molecular biological and molecular cytogenetic analysis of genomic changes in 146 patients with B-cell chronic lymphocytic leukemia. Neoplasma 55: 400-408, 2008. 
144. Amare PS, Gadage V, Jain H, Nikalje S, Manju S, Mittal N, Gujral S and Nair R: Clinico-pathological impact of cytogenetic subgroups in B-cell chronic lymphocytic leukemia: Experience from India. Indian J Cancer 50: 261-267, 2013.

145. Yoon JH, Kim Y, Yahng SA, Shin SH, Lee SE, Cho BS, Eom KS, Kim YJ, Lee S, Kim HJ, et al: Validation of Western common recurrent chromosomal aberrations in Korean chronic lymphocytic leukaemia patients with very low incidence. Hematol Oncol 32: 169-177, 2014

146.Xu W, Li JY, Pan JL, Qiu HR, Shen YF, Li L, Wu YF and Xue YQ: Interphase fluorescence in situ hybridization detection of cytogenetic abnormalities in B-cell chronic lymphocytic leukemia. Int J Hematol 85: 430-436, 2007.
147. Qiu HX, Xu W, Cao XS, Zhou M, Shen YF, Xu YL, Sun XM, Liu Q, Wang R, Qiu HR, et al: Cytogenetic characterisation in Chinese patients with chronic lymphocytic leukemia: A prospective, multicenter study on 143 cases analysed with interphase fluorescence in situ hybridisation. Leuk Lymphoma 49: 1887-1892, 2008.

148. Wang DM, Miao KR, Fan L, Qiu HR, Fang C, Zhu DX, Qiu HX, $\mathrm{Xu} \mathrm{W}$ and $\mathrm{Li} \mathrm{JY}$ : Intermediate prognosis of $6 \mathrm{q}$ deletion in chronic lymphocytic leukemia. Leuk Lymphoma 52: 230-237, 2011. 